\title{
Effect of feeding colostrum at different volumes and subsequent number of transition milk feeds on the serum immunoglobulin G concentration and health status of dairy calves
}

\author{
M. Conneely, ${ }^{*} †$ D. P. Berry, ${ }^{*}$ J. P. Murphy, ${ }^{*}$ I. Lorenz,† M. L. Doherty, $†$ and E. Kennedy ${ }^{* 1}$ \\ ${ }^{*}$ Teagasc, Animal \& Grassland Research and Innovation Centre, Moorepark, Fermoy, Co. Cork, Ireland \\ †School of Veterinary Medicine, University College Dublin, Dublin 4, Ireland
}

\begin{abstract}
Transfer of sufficient IgG to the newborn calf via colostrum is vital to provide it with adequate immunological protection and resistance to disease. The objectives of the present study were to compare serum IgG concentration and health parameters of calves (1) fed different volumes of colostrum [7, 8.5, or $10 \%$ of body weight (BW)] within $2 \mathrm{~h}$ of birth and (2) given 0,2 , or 4 subsequent feedings of transition milk (i.e., milkings 2 to 6 postcalving). Ninety-nine dairy calves were fed $7,8.5$, or $10 \%$ of BW in colostrum within 2 $\mathrm{h}$ of birth and given 0,2 , or 4 subsequent feedings of transition milk. The concentration of IgG in the serum of calves was measured at 24, 48, 72, and $642 \mathrm{~h}$ of age by an ELISA. The apparent efficiency of absorption for IgG was determined. Health scores were assigned to calves twice per week and all episodes of disease were recorded. The effect of experimental treatment on calf serum $\operatorname{IgG}$ concentration differed by the age of the calf. Calves fed $8.5 \%$ of BW in colostrum had a greater mean serum $\operatorname{IgG}$ concentration than calves fed 7 or $10 \%$ of BW at 24,48 , and $72 \mathrm{~h}$ of age. At $642 \mathrm{~h}$ of age, serum IgG concentrations of calves fed $8.5 \%$ of $\mathrm{BW}$ $(24.2 \mathrm{~g} / \mathrm{L})$ and calves fed $10 \%$ of BW $(21.6 \mathrm{~g} / \mathrm{L})$ did not differ, although the serum IgG concentration of calves fed $8.5 \%$ of BW was still greater than that of calves fed $7 \%$ of BW $(20.7 \mathrm{~g} / \mathrm{L})$. No difference in serum IgG concentration existed between calves fed $7 \%$ of BW and those fed $10 \%$ of BW at any age. No significant effect of number of subsequent feedings of transition milk on calf serum IgG concentration was detected. The apparent efficiency of absorption of calves fed $8.5 \%$ of BW in colostrum (38\%) was greater than calves fed $7 \%$ of BW in colostrum $(26 \%)$ and tended to be greater than in calves fed $10 \%$ of BW (29\%). Calves fed further feedings of transition milk after the initial feeding of colostrum
\end{abstract}

Received September 17, 2013

Accepted June 1, 2014.

${ }^{1}$ Corresponding author: Emer.Kennedy@teagasc.ie had a lower odds $(0.62 ; 95 \%$ confidence interval: 0.41 to 0.93 ) of being assigned a worse eye/ear score (i.e., a more copious ocular discharge or pronounced ear droop) and a lower odds $(0.5 ; 95 \%$ confidence interval: 0.32 to 0.79 ) of being assigned a worse nasal score (i.e., a more copious and purulent nasal discharge) during the study period relative to calves that received no further feedings of transition milk. In conclusion, calves fed $8.5 \%$ of BW in colostrum within $2 \mathrm{~h}$ of birth achieved a greater concentration of $\operatorname{IgG}$ in serum in the first $3 \mathrm{~d}$ of life than calves fed either 7 or $10 \%$ of BW. Feeding calves transition milk subsequently reduced their odds of being assigned a worse eye/ear and nasal score.

Key words: calf, colostrum, immunoglobulin G

\section{INTRODUCTION}

Provision of a sufficient quantity of good-quality colostrum to the newborn calf is critically important to ensure its health and well-being (Weaver et al., 2000; McGuirk and Collins, 2004). Because the structure of the bovine placenta separates the maternal and fetal blood supplies, a calf is born without immunoglobulins and depends entirely on their absorption from colostrum to gain adequate immunity and protection from pathogenic organisms until development of its own immunity occurs at 3 to $4 \mathrm{wk}$ of age (Godden, 2008). The absorption of immunoglobulins from colostrum is possible only for a short and finite period of time. As soon as the calf is born, the neonatal gut epithelium begins a maturation process that will render it impermeable to immunoglobulins; absorption is greatest within the first $2 \mathrm{~h}$ of life and has ceased completely by $24 \mathrm{~h}$ (Weaver et al., 2000). This transfer of immunoglobulins from the dam to the neonatal calf is termed passive transfer. Adequate passive transfer (APT) is said to have occurred if the IgG concentration in the serum of the calf is $10 \mathrm{~g} / \mathrm{L}$ or greater when sampled between 24 and $48 \mathrm{~h}$ of age (Weaver et al., 2000).

Adequate passive transfer has been shown to have numerous short- and long-term benefits, including reduced risk for pre- and postweaning morbidity and mortality, 
improved rate of weight gain and feed efficiency, and greater milk production and survival in dairy animals (Robison et al., 1988; DeNise et al., 1989). Failure of passive transfer (FPT; serum $\mathrm{IgG}<10 \mathrm{~g} / \mathrm{L}$ at 24 and $48 \mathrm{~h}$ of age) can result in high levels of preweaning mortality during the first $3 \mathrm{wk}$ of life (Wells et al., 1996). Insufficient data exist presently to describe the level of passive transfer in Irish dairy calves or the effect of alternative colostrum feeding practices currently used on Irish farms. However, two-thirds of tests carried out on blood samples taken from calves less than $10 \mathrm{~d}$ old in the Department of Agriculture, Food and the Marine (DAFM, Dublin, Ireland) and Agri-Food and Biosciences Institute (AFBI, Belfast, UK) laboratories in 2011 indicated inadequate transfer of passive immunity (AFBI/DAFM, 2011). Inadequate colostrum feeding practices may be an important contributory factor to the mortality rate of dairy calves in Ireland (6.5\% calves dead in the first 12 mo of life, excluding stillbirths: AIM, 2012).

Whether APT occurs following ingestion of colostrum is dependent on (1) whether the calf ingests a sufficient mass of $\operatorname{IgG}$, which is dependent on the volume and $\operatorname{IgG}$ concentration of the colostrum fed (Godden, 2008), and (2) the efficiency with which this IgG is absorbed; this is most dependent on the time postpartum at which colostrum is ingested (Stott et al., 1979a). Varying recommendations have been made as to the appropriate volume of colostrum that should be fed to the newborn calf (Roy, 1980; Besser et al., 1985; McGuirk and Collins, 2004). Chigerwe et al. (2008) recommended that dairy calves be fed $3 \mathrm{~L}$ of good-quality colostrum (IgG concentration of $>50 \mathrm{~g} / \mathrm{L}$; McGuirk and Collins, 2004) within $2 \mathrm{~h}$ of birth by esophageal tube or at least $2 \mathrm{~L}$ within $4 \mathrm{~h}$ and a total of $4 \mathrm{~L}$ within $12 \mathrm{~h}$ from birth by nipple feeding (Chigerwe et al., 2009). However, variability in birth weight exists among calves; thus, a single recommendation of 1 volume may not be appropriate for every calf. To date, no author has recommended the volume of colostrum as a percentage of the calf's birth weight, fed as a single feeding within $2 \mathrm{~h}$ of birth, which may be expected to achieve APT.

No further transport of IgG into the circulation is possible $24 \mathrm{~h}$ after birth. Nonetheless, transition milk (milkings 2 to 6 postcalving; Godden, 2008) fed subsequently may have beneficial effects, as it contains a greater concentration of IgG than whole milk (Foley and Otterby, 1978) and antibodies remaining in the lumen may provide local immunity against enteric pathogens (Berge et al., 2009).

The 2 objectives of this experiment were to (1) compare serum IgG concentration, health parameters, and weight gain of calves fed different volumes of colostrum
$(7,8.5$, or $10 \%$ of birth BW) within $2 \mathrm{~h}$ of birth, and (2) compare serum IgG concentration, health parameters, and weight gain in calves given no feeding of transition milk compared with calves given either 2 or 4 additional feedings of transition milk.

\section{MATERIALS AND METHODS}

The study was conducted from January 27 to April 9, 2011 at Teagasc Moorepark Research Farm [County Cork, Ireland $\left.\left(52^{\circ} 9^{\prime} \mathrm{N}, 8^{\circ} 16^{\prime} \mathrm{W}\right)\right]$. The study population consisted of 99 dairy calves: 51 Holstein-Friesian (HF), 29 Jersey cross, and $19 \mathrm{HF} \times$ Norwegian Red. Forty-six calves were female and 53 were male. The mean date of birth of the calves was February 12, $2011(\mathrm{SD}=11 \mathrm{~d})$; the mean calf $\mathrm{BW}$ at birth was $36 \mathrm{~kg}(\mathrm{SD}=5.8 \mathrm{~kg})$.

\section{Experimental Treatments and Colostrum Feeding}

The experiment had a $3 \times 3$ factorial design, which included 3 colostrum feeding amounts: (1) $7 \%$ (7C), (2) $8.5 \%(\mathbf{8 . 5 C})$, or $(3) 10 \%(\mathbf{1 0 C})$ of calf $\mathrm{BW}$ in colostrum within $2 \mathrm{~h}$ of birth, and 3 transition milk feeding amounts: (1) no further feedings of transition milk (0), (2) 2 further feedings of transition milk, or (3) 4 further feedings of transition milk (Figure 1). Thus, there were 9 experimental groups in total $(7 \mathrm{C} 0,7 \mathrm{C} 2$, and $7 \mathrm{C} 4 ; 8.5 \mathrm{C} 0,8.5 \mathrm{C} 2$, and $8.5 \mathrm{C} 4$; and $10 \mathrm{C} 0,10 \mathrm{C} 2$, and $10 \mathrm{C} 4)$. Eleven homogeneous blocks of 9 calves were created based on calf breed, sex, and BW at birth. Calves within each block were randomly assigned to 1 of the 9 treatments.

The colostrum fed to all calves at the initial feeding following birth was pooled colostrum obtained at the first milking postcalving from the freshly calved cows; all initial feedings of colostrum were administered by stomach tube. Batches of colostrum were prepared by combining the colostrum from freshly calved cows that were milked at the next standard milking time following calving (0830 and $1530 \mathrm{~h}$ ), and used to feed calves that were born in the intervening hours. Colostrum was stored in the refrigerator before use. No batch of pooled colostrum was stored for longer than $1 \mathrm{~d}$; if it was not used within this period, it was discarded and a fresh pool of colostrum generated.

The transition milk fed at all subsequent feedings was pooled transition milk obtained at the second milking postcalving from the freshly calved cows; all subsequent feedings were given by nipple bottle, and the quantity fed was $2 \mathrm{~L}$. Each batch was fed to calves or discarded within 2 d. Transition milk was stored in large churns in the calf-housing facility; the mean ambient air temperature measured at the experimental 


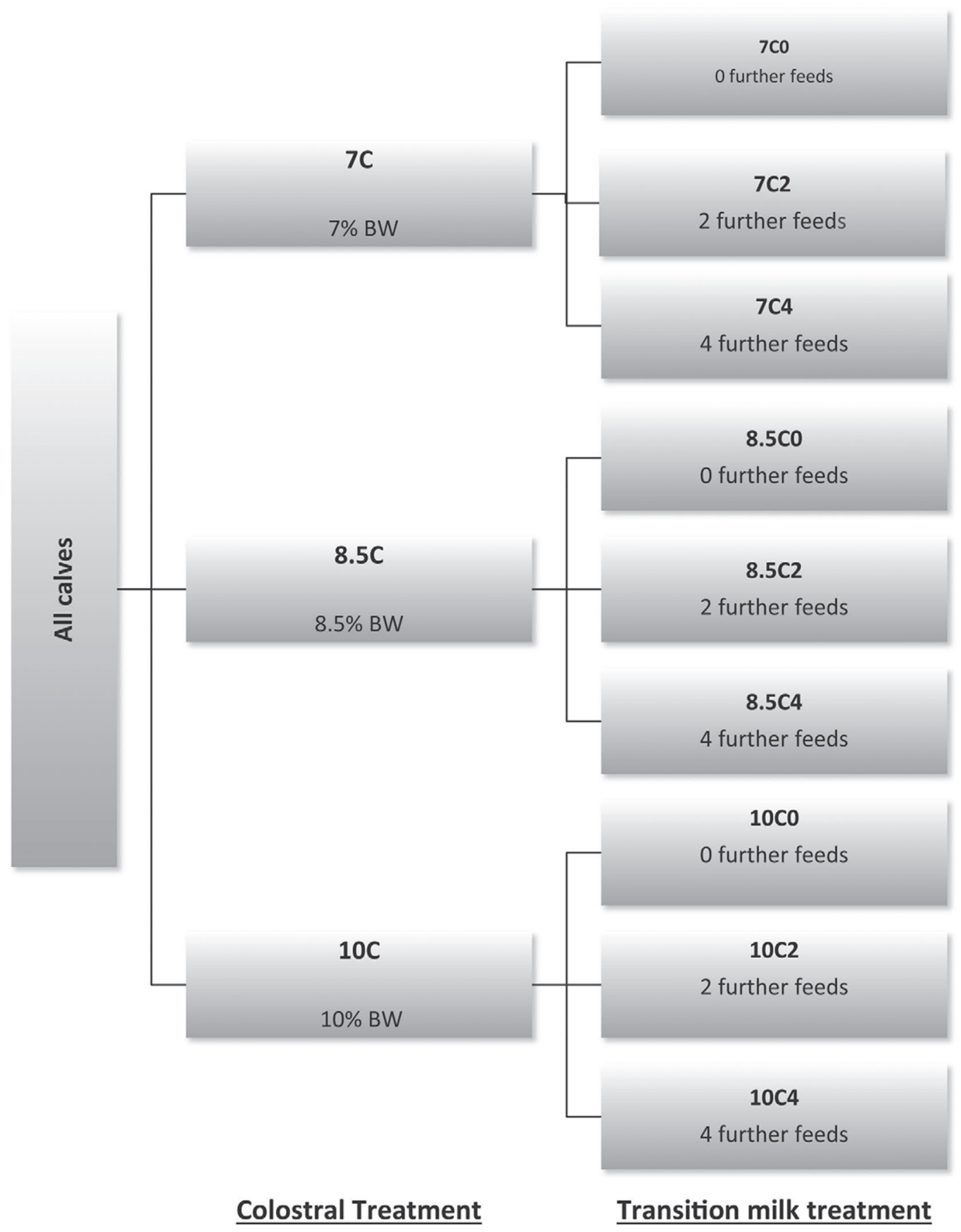

Figure 1. Division of calves into experimental treatment groups and transition milk treatment groups. $7 \mathrm{C}=$ colostrum fed at $7 \%$ of BW; $8.5 \mathrm{C}=$ colostrum fed at $8.5 \%$ of $\mathrm{BW} ; 10 \mathrm{C}=$ colostrum fed at $10 \%$ of $\mathrm{BW}$.

site during the experiment was $6.9^{\circ} \mathrm{C}$ (range: -2.7 to $\left.13.4^{\circ} \mathrm{C}\right)$. The subsequent transition milk feedings were given at the next standard feeding times (0800 and $1500 \mathrm{~h}$ ) unless a calf was born within the $3 \mathrm{~h}$ before the next standard feeding time. In this case, the subsequent transition milk feed was given at the following standard feeding time. Calves that received no further feedings of transition milk were offered whole milk (nonwaste milk produced by the Moorepark milking herd) from their second feeding onwards.

A sample was taken for subsequent IgG analysis from each batch of both first milking colostrum and second 
milking pooled transition milk. These samples were stored at $-20^{\circ} \mathrm{C}$ until analysis.

\section{Management of Calves}

All calving events were observed and attended by trained and competent farm personnel. To ensure the calf did not suckle its dam before feeding of colostrum or blood sampling (detailed below), the calf was removed from the dam before it became ambulatory. Two identically numbered plastic national identification ear tags were applied to each ear of the calf for identification purposes, as required by the Department of Agriculture, Food and the Marine, and the navel of the calf was sprayed with $10 \%$ iodine. Each calf was weighed (Tru-Test XR 3000; Tru-Test Ltd., Auckland, New Zealand), a blood sample was obtained (detailed below) from the calf, and the calf was fed the volume of colostrum dictated by its experimental treatment group.

The calf was then placed in an individual pen measuring $0.8 \times 1.2 \mathrm{~m}$, where it remained for $3 \mathrm{~d}$ and received its respective number of transition milk or whole milk feedings, as per its transition milk treatment group. The calf was subsequently transferred to a group pen measuring $5 \times 7 \mathrm{~m}$. Calves were housed in groups of 18; the largest difference between birth dates was 2 wk. Calves from the different experimental groups were distributed equally between group pens. Calves were turned out to pasture at 4 wk of age, where they grazed in groups of 18 calves per 0.8 -ha paddock.

Following completion of colostrum and transition milk feeding, calves were fed whole milk twice per day at a daily rate of $10 \%$ of calf birth BW until 3 wk of age, when they received the same quantity in a once-daily feed. The total daily milk requirement for the group of calves was calculated by summing the individual daily milk requirement of each calf and milk was fed via a group calf nipple feeder. Calves were weaned once they had attained specific target weights for their breed (90 $\mathrm{kg}$ for HF, $80 \mathrm{~kg}$ for $\mathrm{HF} \times$ Norwegian Red, and $75 \mathrm{~kg}$ for Jersey cross). The calves were then removed from the group of calves with which they were grazing and gradually weaned during the following week. All calves were managed similarly postweaning and had full-time access to pasture plus $1 \mathrm{~kg}$ of supplementary concentrate feed offered per day.

Fresh water was available at all times and ad libitum concentrate and hay were offered from $4 \mathrm{~d}$ of age while the calves were housed in group pens. The general health of the calves was monitored daily by a veterinarian; any animal that became ill received the appropriate care and veterinary treatment as required.

\section{Data Collection and Analysis}

Collection of Calf Serum. A 6-mL blood sample was taken from the jugular vein of each calf into a plain serum tube (BD Vacutainer; BD, Langenbach, Germany) within $1 \mathrm{~h}$ of birth, before feeding colostrum $(0 \mathrm{~h})$. Blood samples were subsequently taken from each calf at 24, 48, and $72 \mathrm{~h}$ after the initial feeding of colostrum. A final blood sample was taken from each calf between 3 and 4 wk of age (i.e., $642 \mathrm{~h}$ of age). Blood samples were refrigerated for $24 \mathrm{~h}$ before serum was separated by centrifugation at $3,500 \times g$ for $15 \mathrm{~min}$ at $4^{\circ} \mathrm{C}$ and frozen at $-20^{\circ} \mathrm{C}$ before $\operatorname{IgG}$ concentration determination.

Determination of IgG Concentration of Serum and Pooled Colostrum. The IgG concentration in serum and colostrum (details of the colostrumtesting protocol were published previously; Conneely et al., 2013) was determined by an ELISA (Bovine IgG ELISA Kit, catalog no. 8010; Alpha Diagnostic International Inc., San Antonio, TX). Samples were assayed in duplicate, with an interassay coefficient of variation of 0.15. The concentration of IgG in samples was calculated from a standard reference curve containing known concentrations of IgG. Any sample that resulted in an IgG concentration that fell outside the range of the standard reference curve was retested after further dilution according to the test recommendations.

Collection of Calf Health Data. Individual animal health scores were assigned to calves on a twiceweekly basis by a single veterinarian. Heifer calves were scored from birth until weaning at approximately 12 wk of age; scores were assigned to male calves from birth until they were sold between 3 and 4 wk of age. Health scores were assigned using a calf health scoring system developed by the School of Veterinary Medicine, University of Wisconsin-Madison (http:// www.vetmed.wisc.edu/dms/fapm/fapmtools/8calf/ calf_health_scoring_chart.pdf). Calves were scored on 4 different aspects of health: nasal, eye/ear, fecal, and cough. Each individual aspect received a score from 0 to 3,0 representing normal and 3 representing the most severely affected.

Determination of Apparent Efficiency of Absorption. Apparent efficiency of absorption (AEA) estimates efficiency of immunoglobulin absorption before cessation of intestinal absorption of immunoglobulins (Quigley et al., 1998). Apparent efficiency of absorption for IgG was determined as previously described (Quigley et al., 1998, 2002) using the following formula:

$$
\begin{aligned}
\mathrm{AEA}= & {[\text { serum } \operatorname{IgG}(\mathrm{g} / \mathrm{L}) \times \text { plasma volume }} \\
& (\mathrm{L}) / \operatorname{IgG} \text { intake }(\mathrm{g})] \times 100 .
\end{aligned}
$$


The plasma volume was calculated as follows: plasma volume $=0.089 \times[\mathrm{BW}$ at birth $(\mathrm{kg})]$ (Quigley et al. 1998).

\section{Data Editing and Statistical Analysis}

Calf Serum IgG. The concentration of IgG in the calf serum was normally distributed. A fixed-effects model in PROC GLM in SAS (version 9.1; SAS Institute Inc., Cary, NC) was used to establish whether serum IgG at $0 \mathrm{~h}$ differed between experimental groups before feeding of colostrum. The independent variable was colostral treatment of calf. A mixed model in PROC MIXED in SAS was also used to establish whether the IgG concentration of the pooled colostrum fed at the first feeding after birth differed between experimental groups. The independent variable was colostral treatment of calf; experimental block was included as a random effect.

Mixed models in PROC MIXED were also used to determine the effect of colostral treatment and transition milk treatment on serum IgG concentration at different ages. Independent variables considered for inclusion in the model included colostral treatment group of calf, transition milk treatment group, and age of calf when serum was sampled $(24,48$, or $72 \mathrm{~h}$, or $4 \mathrm{wk})$. Interactions between colostral treatment and transition milk treatment, colostral treatment and age, and transition milk treatment and age were also considered in the model. Blood sample was included as a repeated effect and a compound symmetry covariance structure with heterogeneous variances assumed among records within calf. Experimental block was included as a random effect. The mean IgG concentration of the colostrum and transition milk fed to each calf in the first $24 \mathrm{~h}$ of life was considered as a covariate in the model, as was the $\operatorname{IgG}$ concentration of the first colostral feeding. Because the subsequent transition milk feedings took place at fixed times during the day (0800 and 1500 $\mathrm{h}$ ), and because of the spread in the actual times of birth of each calf, variation existed in the number of opportunities each calf had to receive subsequent transition milk feeds before cessation of IgG absorption at $24 \mathrm{~h}$ of age, depending on their time of birth. As such, calves in the same treatment group may have received a different number of subsequent transition milk feeds before $24 \mathrm{~h}$ of age. Thus, the time of birth of the calf was considered as a covariate also. Time of birth of the calf was categorized as (1) calf born between 0500 and $0800 \mathrm{~h}$, with next transition milk feeding at 1500 h; (2) calf born between 0800 and $1200 \mathrm{~h}$, with next transition milk feeding at $1500 \mathrm{~h}$; (3) calf born between 1200 and $1500 \mathrm{~h}$, with next transition milk feed at 0800 h; or (4) calf born between 1500 and $0500 \mathrm{~h}$, with next transition milk feed at $0800 \mathrm{~h}$. Mean IgG concentration of the colostrum and transition milk fed to each calf in the first $24 \mathrm{~h}$ of life, the IgG concentration of the first colostral feeding, and time of birth of the calf were not associated with the dependent variable (serum IgG concentration) and, thus, were not considered further.

$\boldsymbol{A} \boldsymbol{E} \boldsymbol{A}$. Apparent efficiency of absorption was calculated for 84 of the 99 calves. Data required to calculate the AEA (six 48-h serum IgG concentrations and 9 total IgG concentrations fed in the first $24 \mathrm{~h}$ ) were missing for 15 of the 99 calves and so these were excluded from the analysis. A mixed model in PROC MIXED in SAS was used to establish whether the experimental treatment of calf affected the AEA of IgG at $48 \mathrm{~h}$ of age. The independent variable was colostral treatment of calf; experimental block was included as a random effect.

Calf Health Scores. A total of 1,783 individual calf health scores from 99 calves were available for analysis. For each health aspect separately, the probability of a calf having a higher health score (i.e., worse score) within the study period was modeled by ordinal regression in PROC GLIMMIX (version 9.1; SAS Institute Inc., Cary, NC) using a cumulative logit link function and assuming a multinomial distribution of the data. Calf, nested within colostral treatment $\times$ transition milk treatment, was included as a repeated effect. A random effect of block (while indoors) and block within paddock (when outdoors) was considered in the model to account for the hierarchical structure in the data across time. The model included colostral treatment group, transition milk treatment group, and age of the calf in days when assessed. The age of the calf was considered as a continuous variable. The number of days a calf was present in the study before it was weaned or sold was also included as a covariate in the model. Two-way interactions were also tested in the model. In addition, an orthogonal contrast was used to compare the transition milk treatment groups that received no further feedings of transition milk, combined, with the transition milk treatment groups that received further feeds of transition milk. Significance was declared at $P<0.05$. Odds ratios and 95\% upper and lower confidence intervals were calculated. Odds ratios were calculated by acquiring the exponent of the regression coefficients. Odds ratios compare opposing probabilities to determine which is the more likely result for a given outcome; in this instance, the probability of a calf being assigned a worse score (i.e., indicative of the calf displaying a more severe form of the variable in question). An odds ratio greater than 1 implies an increased likelihood of the outcome in question. 
Table 1. Mean IgG concentration of colostrum (SD in parentheses), volume, and range in volume of colostrum fed to 99 dairy calves at $7,8.5$, or $10 \%$ of BW within $2 \mathrm{~h}$ of birth

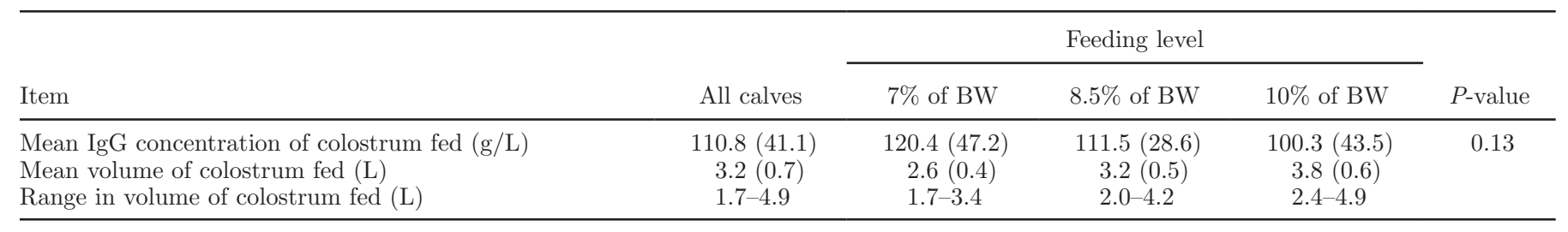

\section{RESULTS}

\section{IgG Concentration of Colostrum Fed to Calves}

The mean concentration of IgG in the colostrum fed to all calves at the first feeding was $110.8 \mathrm{~g} / \mathrm{L}$ (SD $=41.1 \mathrm{~g} / \mathrm{L})$. No significant difference existed in IgG concentration of the colostrum that was fed to the different colostral treatment groups $(P=0.13)$. The mean concentrations of IgG in the colostrum fed to calves in the $7 \mathrm{C}, 8.5 \mathrm{C}$, and $10 \mathrm{C}$ treatment groups are in Table 1.

\section{Serum $\lg G$}

The concentration of IgG in serum sampled at $0 \mathrm{~h}$ was $1.03 \mathrm{~g} / \mathrm{L}(\mathrm{SE}=0.3)$ and did not differ significantly between colostral treatment groups $(P=0.11)$. The effect of colostral treatment on serum IgG differed with age of calf $(P<0.05$; Figure 2$)$. At $24 \mathrm{~h}$ of age, calves fed $8.5 \%$ of BW in colostrum had a greater concentration of $\mathrm{IgG}$ in serum $(39.1 \mathrm{~g} / \mathrm{L})$ than both calves fed $7 \%$ of BW $(30.3 \mathrm{~g} / \mathrm{L} ; P<0.001)$ and calves fed $10 \%$ of BW $(31.2 \mathrm{~g} / \mathrm{L} ; P<0.001)$. At $48 \mathrm{~h}$ of age, serum IgG concentration had declined for all 3 groups, but the calves fed $8.5 \%$ of $\mathrm{BW}$ in colostrum still had a greater serum IgG concentration than both calves fed $7 \%$ of BW and calves fed $10 \%$ of BW. At $72 \mathrm{~h}$ of age, serum IgG concentrations had declined further for all 3 groups, but similarly, calves fed $8.5 \%$ of BW in colostrum had a greater concentration of IgG in serum than both calves fed $7 \%$ of BW and calves fed $10 \%$ of BW. At $642 \mathrm{~h}$ of age, the concentration of $\operatorname{IgG}$ in serum of calves fed $8.5 \%$ of BW $(24.2 \mathrm{~g} / \mathrm{L})$ was still greater than those fed $7 \%(20.6 \mathrm{~g} / \mathrm{L} ; P<0.05)$, but was no longer greater than that of calves fed $10 \%$ of BW $(21.5 \mathrm{~g} / \mathrm{L} ; P$ $=0.12$ ). No difference existed in serum IgG concentration between calves fed $7 \%$ of $\mathrm{BW}$ and those fed $10 \%$ at any age.

Irrespective of colostral treatment group, peak IgG concentration occurred at $24 \mathrm{~h}$ of age, and decreased thereafter (Figure 2); the lowest serum IgG concentration was measured at $4 \mathrm{wk}$ of age.

No significant effect was detected of transition milk treatment $(P=0.92)$, transition milk treatment $\times$ age of calf interaction $(P=0.94)$, or colostral treatment $\times$ transition milk treatment interaction $(P=0.06)$ on the serum IgG concentration of calves.

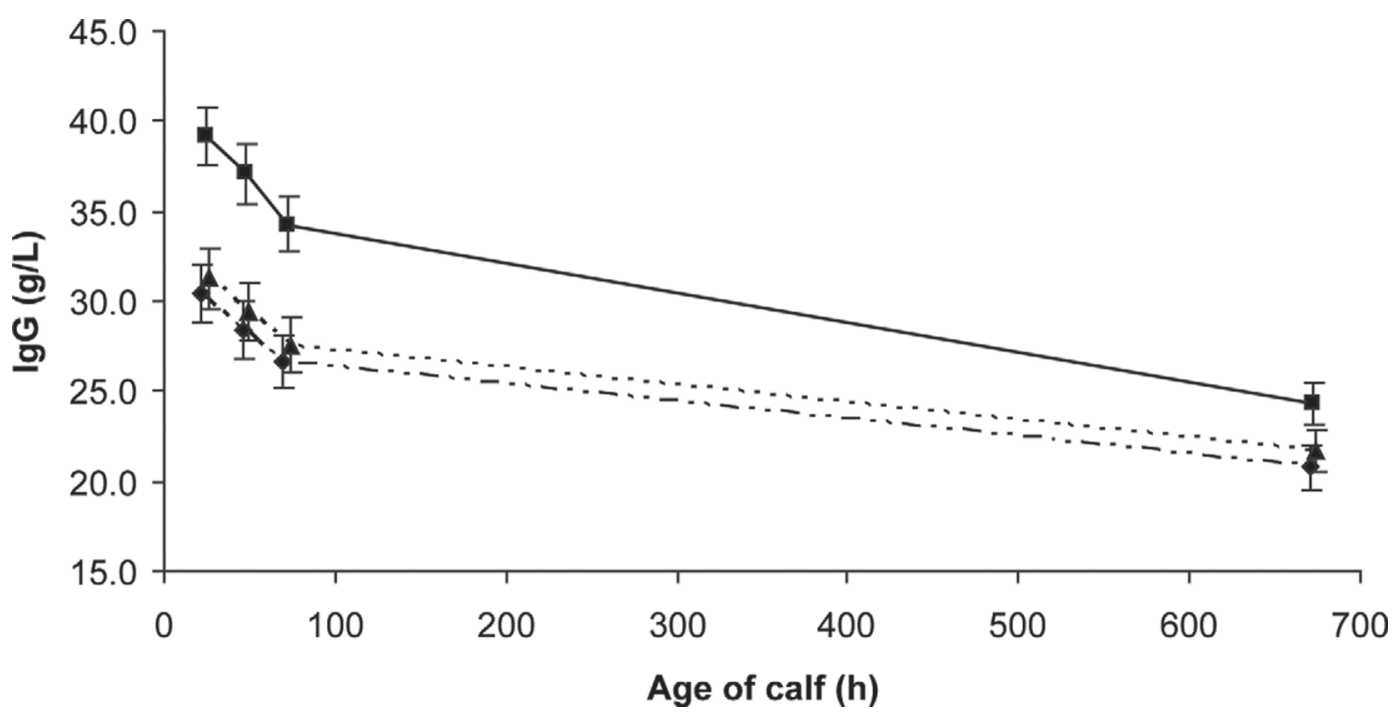

Figure 2. Mean serum IgG concentration (g/L) at 24, 48, 72, and $672 \mathrm{~h}$ of age for calves fed $7 \%$ of BW (--- --), $8.5 \%$ of BW (- - - ) and $10 \%$ of BW (-- $\mathbf{\Delta}_{--}$in colostrum within $2 \mathrm{~h}$ of birth. Error bars represent $1 \mathrm{SE}$ on each side of the LSM. 


\section{AEA}

The mean AEA of calves fed $8.5 \%$ of BW in colostrum $(38 \%$; SE $=4 \%)$ was greater than that of calves fed $7 \%$ of $\mathrm{BW}$ in colostrum $(26 \%$; $\mathrm{SE}=3 \% ; P<0.01)$ and tended to be greater than that of calves fed $10 \%$ of BW $(29 \%$; $\mathrm{SE}=3 \% ; P=0.07)$.

\section{Health Scores}

The overall prevalence of scores indicating normal health was high; 91, 88, 95, and 95\% of scores assigned for the nasal, eye/ear, cough, and fecal consistency aspects of health, respectively, indicated normal health (score of 0 ). Scores of 2 and 3 were assigned for 8 and $2 \%$ of nasal scores, 9 and $3 \%$ of eye/ear scores, 1 and $4 \%$ of cough scores, and 3 and $1 \%$ of fecal consistency scores, respectively. Less than $1 \%$ of scores assigned were indicative of severely abnormal health (score of 3 ). Mean scores for the 4 different aspects of health are given in Table 2 .

Age of a calf affected its likelihood of being assigned a worse (i.e., higher) nasal $(P \leq 0.001)$, eye/ear $(P<$ $0.01)$, cough $(P<0.001)$, or fecal $(P<0.001)$ score within the study period. For the nasal, eye/ear, and cough aspects of health, the likelihood of a calf being assigned a worse score increased nonlinearly with age. The likelihood of worse nasal, eye/ear, and cough score was greatest at 56, 29, and $45 \mathrm{~d}$ of age, respectively. The cumulative logit of a calf being assigned a worse fecal score decreased linearly with age.

Colostral treatment had no effect on the likelihood of a calf being assigned a worse nasal $(P=0.32)$, eye/ear $(P=0.099)$, cough $(P=0.56)$, or fecal $(P=0.33)$ score within the study period. Transition milk treatment of calf had no effect on the likelihood of a calf exhibiting a worse cough $(P=0.61)$ or fecal $(P=0.43)$ score within the study period.

Calves receiving further feedings of transition milk subsequent to the initial feeding of colostrum had lower odds $(0.62 ; 95 \% \mathrm{CI}: 0.41$ to $0.93 ; P<0.05)$ of being assigned a worse eye/ear score during the study period, and lower odds $(0.5 ; 95 \% \mathrm{CI}: 0.32$ to $0.79 ; P<0.01)$ of being assigned a worse nasal score during the study period, relative to calves that received no further feedings of transition milk. Relative to calves that received no further feedings of transition milk, the odds of a calf being assigned a worse eye/ear score during the study period were 0.51 (95\% CI: 0.32 to $0.84 ; P<0.05)$ and 0.73 (95\% CI: 0.47 to $1.13 ; P<0.05$ ) for calves that received 2 and 4 subsequent feedings of transition milk, respectively.

Relative to calves that received no further feedings of transition milk, the odds of a calf being assigned a worse nasal score during the study period were 0.48 (95\% CI: 0.28 to $0.84 ; P<0.05$ ) for calves that received both 2 and 4 subsequent feeds of transition milk.

\section{DISCUSSION}

Achieving a sufficiently high concentration of $\operatorname{IgG}$ in serum by $24 \mathrm{~h}$ of age is critically important to ensure the health and well-being of the newborn calf (Godden, 2008). In the present study, the concentration of $\operatorname{IgG}$ measured in the serum of calves following administration of colostrum was generally high (mean serum IgG at $24 \mathrm{~h}$ of age was $33.7 \mathrm{~g} / \mathrm{L}$ ). This level is greater than some previous studies; mean calf serum IgG concentrations of $18.7,9.8$, and $9.4 \mathrm{~g} / \mathrm{L}$ were reported in studies by Godden et al. (2009), Furman Fratczak et al. (2011), and Sakai et al. (2012), respectively. The high serum IgG concentrations of calves in the present study are most likely a result of their early consumption of a large quantity of high-IgG colostrum. None of the calves in the present study had a serum IgG at $24 \mathrm{~h}$ of age of less than $10 \mathrm{~g} / \mathrm{L}$, and only 2 calves had serum IgG concentration below $15 \mathrm{~g} / \mathrm{L}$. Although variation exists in the threshold value for a serum IgG concentration that defines FPT, a serum IgG concentration of $10 \mathrm{mg} / \mathrm{mL}$ at $24 \mathrm{~h}$ of age is currently accepted as the threshold between FPT and APT (Weaver et al., 2000; Beam et al., 2009). Thus, all of the calves in the study

Table 2. Mean scores (SD in parentheses) for nasal, eye/ear, fecal, and cough aspects of health of 99 dairy calves fed colostrum at $7,8.5$, or $10 \%$ of BW within $2 \mathrm{~h}$ of birth, and calves given 0,2 , or 4 subsequent feedings of transition milk

\begin{tabular}{|c|c|c|c|c|c|c|}
\hline \multirow{3}{*}{$\begin{array}{l}\text { Health } \\
\text { aspect }\end{array}$} & \multicolumn{6}{|c|}{ Treatment } \\
\hline & \multicolumn{3}{|c|}{ Colostral treatment } & \multicolumn{3}{|c|}{ Transition milk } \\
\hline & $7 \%$ & $8.5 \%$ & $10 \%$ & 0 & 2 & 4 \\
\hline Nasal & $0.09(0.034)$ & $0.11(0.36)$ & $0.12(0.37)$ & $0.16(0.44)$ & $0.09(0.32)$ & $0.09(0.33)$ \\
\hline Eye/Ear & $0.17(0.15)$ & $0.13(0.41)$ & $0.21(0.59)$ & $0.22(0.58)$ & $0.12(0.4)$ & $0.17(0.48)$ \\
\hline Fecal & $0.07(0.37)$ & $0.05(0.29)$ & $0.08(0.34)$ & $0.04(0.27)$ & $0.05(0.3)$ & $0.08(0.4)$ \\
\hline Cough & $0.11(0.44)$ & $0.10(0.41)$ & $0.08(0.38)$ & $0.09(0.41)$ & $0.1(0.42)$ & $0.09(0.4)$ \\
\hline
\end{tabular}


achieved APT following administration of colostrum. Early intake of high-quality colostrum is one probable reason for the high serum IgG concentration of calves in the present study. Timing of colostrum feeding is one of the most critical determinants of efficient immunoglobulin absorption (Weaver et al., 2000; Beam et al., 2009), as the ability of the neonatal gut to absorb immunoglobulins declines progressively from $2 \mathrm{~h}$ of age (Chigerwe et al., 2008) and substantially larger IgG intakes are required by calves provided colostrum after $2 \mathrm{~h}$ from birth to achieve APT. All calves in the present study received their first colostral feeding within $2 \mathrm{~h}$ of birth, compared with, for example, only $69.7 \%$ of calves in the study by Furman-Fratczak et al. (2011).

The high IgG concentration of the colostrum fed to calves in the present study $(110.8 \mathrm{~g} / \mathrm{L})$ undoubtedly contributed to the high serum IgG level, as concentration of IgG in colostrum is a critical factor in ensuring adequate absorption by the calf (Pritchett et al., 1991). Furthermore, in the present study, the average volume of colostrum fed to calves at their first feeding was high $(3.2 \mathrm{~L})$, and $60 \%$ of calves ingested over $3 \mathrm{~L}$ at their first feeding. This high mean volume of colostrum fed to calves was likely to have also contributed to the high serum IgG concentration of calves, as the volume of colostrum fed is an important factor in determining serum IgG concentration (Stott et al., 1979c).

\section{Effect of Volume}

Consistent with previous studies (Husband et al., 1972; Burton et al., 1989; Morin et al., 1997), the concentration of IgG in neonatal serum was negligible before feeding of colostrum, reached a maximum at 24 $\mathrm{h}$ of age, and declined thereafter. At each sample time point, the $8.5 \mathrm{C}$ group had a greater serum IgG concentration than either the $10 \mathrm{C}$ or the $7 \mathrm{C}$ groups; only at 4 wk of age did the difference between the $8.5 \mathrm{C}$ group and the $10 \mathrm{C}$ group disappear. As the calf's own immunity develops in the early weeks of life, the relative contribution of maternal immunoglobulins to overall serum immunoglobulin level becomes less important (Devery et al., 1979) and, thus, it is not surprising that by 4 wk of age, a difference in serum IgG concentrations no longer existed between the $8.5 \mathrm{C}$ and $10 \mathrm{C}$ groups. The reason why the difference remained between the $8.5 \mathrm{C}$ group and the $7 \mathrm{C}$ group is not clear, however. The concentration of the colostrum fed to the calves in treatment group $8.5 \mathrm{C}$ was not greater than that fed to calves in the other experimental groups (Table 2 ), so this does not explain why these calves achieved significantly higher serum IgG concentrations following colostrum feeding. The greater concentration possibly resulted from greater absorption efficiency by the calves fed $8.5 \%$ of BW.

Although it is well established that the volume of colostrum fed is one of the critical factors determining serum IgG concentration (Stott et al., 1979c), it appears that increasing the quantity of colostrum fed may increase serum IgG only up to a point, after which a law of diminishing returns may come into play. Besser et al. (1985) reported a negative correlation between the efficiency of absorption and the mass of IgG fed and suggested a physiological limitation to the mass of immunoglobulin that can be absorbed from a given volume of colostrum, resulting from saturation of a shared macromolecular transport mechanism across the calf intestinal epithelium. Stott et al. (1979c) also hypothesized that an excessive amount of colostrum may inhibit absorption of immunoglobulin for the same reason, and suggested that a limited quantity of colostrum containing a high concentration of IgG could result in better absorption than a large quantity of colostrum containing a low concentration of IgG. Stott and Fellah (1983) reported that the immunoglobulin in $1 \mathrm{~L}$ of colostrum was absorbed more efficiently than an equivalent mass of immunoglobulin in $2 \mathrm{~L}$ of colostrum when IgG concentration was greater than $20 \mathrm{~g} / \mathrm{L}$ in colostrum. Jaster (2005) reported higher serum IgG concentrations in calves fed $2 \mathrm{~L}$ at birth and $2 \mathrm{~L}$ at 12 $\mathrm{h}$ rather than $4 \mathrm{~L}$ at birth.

Another possible reason for a reduction in the absorption efficiency of $\operatorname{IgG}$ when calves are fed large volumes of colostrum in a single feeding is mechanical distension of the abomasum and other forestomachs, leading to a reduction in abomasal emptying. The rate of abomasal emptying is a factor affecting colostral $\mathrm{IgG}$ absorption (Mokhber-Dezfooli et al., 2012) and, thus, slower abomasal emptying may result in decreased absorption of colostral components (Sakai et al., 2012). Chigerwe et al. (2008) reported that calves fed $4 \mathrm{~L}$ of colostrum had reduced serum IgG concentration at $48 \mathrm{~h}$ of age compared with calves fed $3 \mathrm{~L}$ of colostrum. In the present study, the average volume of colostrum fed to the calves on the $10 \mathrm{C}$ treatment was close to $4 \mathrm{~L}$ (Table 1 ), and as calves in the present study were smaller than the Holstein bull calves used in the abovementioned study (40.9 kg; Chigerwe et al., 2008), the amount of abomasal distension caused by a given volume of colostrum would be relatively greater. Ninety-one percent of calves were fed over $3 \mathrm{~L}$ of colostrum at the first feeding and $41 \%$ were fed over $4 \mathrm{~L}$; in contrast, only $9 \%$ of calves on the $8.5 \mathrm{C}$ treatment consumed volumes exceeding $4 \mathrm{~L}$. It is possible that these large volumes of colostrum fed may have caused mechanical distension and a reduction in the rate of abomasal emptying in calves of the $10 \mathrm{C}$ 
treatment group, thereby reducing their absorption of IgG. Of course, larger calves will have proportionately larger abomasa but it appears that when colostrum was fed at $10 \%$ of BW, the volume may have been too great to facilitate an optimum rate of abomasal emptying, regardless of the actual number of liters fed.

That the lower volumes of colostrum fed to calves in the $7 \mathrm{C}$ group did not result in a reduced serum IgG concentration is likely due to the fact that the colostrum they received was of very high quality and contained a sufficiently high mass of IgG to achieve high levels of $\mathrm{IgG}$ in serum. A minimum of $150 \mathrm{~g}$ of $\mathrm{IgG}$ is required by a calf to achieve passive transfer (Chigerwe et al., 2008); the average mass of $\operatorname{IgG}$ delivered to calves in the 7C group ( $317 \mathrm{~g}$; SD = $144 \mathrm{~g}$ ) at the first feeding was, therefore, more than twice the quantity necessary to ensure optimal transfer of immunity.

\section{Effect of Further Feedings of Transition Milk}

The finding that providing calves with further feedings of transition milk following the initial feeding of colostrum had no effect on serum IgG concentrations is not unexpected. Absorption of the IgG molecule by nonselective pinocytosis (Besser et al., 1985) by the neonatal gut is only possible for a limited time after birth. Immunoglobulin transfer across the gut epithelium is optimal in the first $4 \mathrm{~h}$ after birth (Stott et al., 1979b); this absorptive capacity begins to decline rapidly after $2 \mathrm{~h}$ of age (Chigerwe et al., 2008), and by $24 \mathrm{~h}$ of age after birth no further transport is possible (Weaver et al., 2000). Although all of the calves received the feeding of transition milk before gut closure at $24 \mathrm{~h}$ and, thus, may have been capable of absorbing the additional IgG present in the transition milk, the time from birth to the second feeding was long (mean $=11 \mathrm{~h}$; $\mathrm{SD}=5 \mathrm{~h}$; range $=3$ to $20 \mathrm{~h}$ ), and $56 \%$ of calves received their first feeding of transition milk $>12 \mathrm{~h}$ following birth. Thus, the absorption of whatever level of IgG was present in the milk was undoubtedly much less, and ultimately of little consequence. It is possible that the delay in time from the ingestion of the IgG in the transition milk and its appearance in the serum subsequently may have prevented the contribution of the IgG from the feeding of transition milk being seen at $24 \mathrm{~h}$ of age. However, calves receiving further feedings of transition milk did not have elevated IgG levels at $48 \mathrm{~h}$, despite the fact that the $\operatorname{IgG}$ concentration of the transition milk fed $(63.3 \mathrm{~g} / \mathrm{L})$ was greater than the threshold used to define colostrum as being of good quality (50 g/L; McGuirk and Collins, 2004). This reinforces the well-established fact that it is the early intake of high-quality colostrum that is the critical determinant in achieving high $\operatorname{IgG}$ concentrations in calf serum (Godden, 2008).
The feeding of transition milk to calves for several days following the initial feeding of colostrum is commonplace on many farms; however, the benefits of this practice remain unclear. Although some studies have reported that continued feeding of colostrum following cessation of absorption of IgG by the neonatal gut resulted in reduced incidence of diarrhea due to localized protective effects of antibodies remaining in the gut lumen (Berge et al., 2009), others have not. Nocek et al. (1984) reported that continued feeding of colostrum until weaning at $45 \mathrm{~d}$ of age resulted in an overall increased severity of scouring, increased percentage of calf days scouring, days treated, and calf days with temperatures greater than $37.8^{\circ} \mathrm{C}$ compared with calves receiving milk replacer. In the present study, providing calves further feedings of transition milk following the initial feeding had no effect on the likelihood of being assigned a worse fecal score throughout the study period.

The finding that calves receiving further feedings of transition milk had a lower likelihood of being assigned a worse eye/ear and nasal score during the study period is an interesting result. Perhaps the localized protective effects of antibodies remaining in the lumen protected against entry of pathogens, or it is possible that some growth factors and cytokines present (Godden, 2008) may have had some immune-enhancing effect that was unrelated to immunoglobulins. Although total IgG levels are useful and commonly used measures of passive transfer and protection from neonatal disease, colostrum provides many other nutritional factors and specific and nonspecific immune factors that may influence short- and long-term health and performance of the animal (Kehoe et al., 2007). This is an area that warrants further research.

\section{CONCLUSIONS}

Calves fed $8.5 \%$ of BW in colostrum within $2 \mathrm{~h}$ of birth achieved a greater concentration of IgG in serum in the first $3 \mathrm{~d}$ of life than calves fed 7 or $10 \%$ of BW. Feeding calves transition milk subsequently reduced their odds of being assigned a worse eye/ear and nasal score.

\section{REFERENCES}

AFBI/DAFM (Agri-Food and Biosciences Institute/Department of Agriculture, Food and the Marine). 2011. All-Island Animal Disease Surveillance Report 2011. Accessed Sep. 17, 2013. http:// www.afbini.gov.uk/all-island_animal_disease_surveillance_report 2011reduced.pdf.

AIM (Animal Identification and Movement System). 2012. AIM Bovine Statistics Report 2012. Department of Agriculture, Food and the Marine, Dublin, Ireland. Accessed Sep. 17, 2013. http:// www.agriculture.gov.ie/media/migration/animalhealthwelfare/ 
animalidentificationandmovement/AIMBOVINESTATISTICS REPORT2012220513.pdf.

Beam, A. L., J. E. Lombard, C. A. Kopral, L. P. Garber, A. L. Winter, J. A. Hicks, and J. L. Schlater. 2009. Prevalence of failure of passive transfer of immunity in newborn heifer calves and associated management practices on US dairy operations. J. Dairy Sci. 92:3973-3980.

Berge, A. C. B., T. E. Besser, D. A. Moore, and W. M. Sisco. 2009. Evaluation of the effects of oral colostrum supplementation during the first fourteen days on the health and performance of preweaned calves. J. Dairy Sci. 92:286-295.

Besser, T. E., A. E. Garmedia, M. A. McGuire, and C. C. Gay. 1985. Effect of colostral immunoglobulin $\mathrm{G}_{1}$ and immunoglobulin $\mathrm{M}$ concentrations on immunoglobulin absorption in calves. J. Dairy Sci. 68:2033-2037.

Burton, J. L., B. W. Kennedy, E. B. Burnside, B. N. Wilkie, and J. H. Burton. 1989. Variation in serum concentrations of immunoglobulins G, A, and M in Canadian Holstein-Friesian calves. J. Dairy Sci. 72:135-149.

Chigerwe, M., J. W. Tyler, L. G. Schultz, J. R. Middleton, B. J. Steevens, and J. N. Spain. 2008. Effect of colostrum administration by use of oroesophageal intubation on serum IgG concentrations in Holstein bull calves. Am. J. Vet. Res. 69:1158-1163.

Chigerwe, M., J. W. Tyler, M. K. Summers, J. R. Middleton, L. G. Schultz, and D. W. Nagy. 2009. Evaluation of factors affecting serum IgG concentrations in bottle-fed calves. J. Am. Vet. Med. Assoc. 234:785-789.

Conneely, M., D. P. Berry, R. Sayers, J. P. Murphy, I. Lorenz, M. L. Doherty, and E. Kennedy. 2013. Factors associated with the concentration of immunoglobulin $\mathrm{G}$ in the colostrum of dairy cows. Animal 7:1824-1832.

DeNise, S. K., J. D. Robison, G. H. Stott, and D. V. Armstrong. 1989. Effects of passive immunity on subsequent production in dairy heifers. J. Dairy Sci. 72:552-554.

Devery, J. E., C. L. Davis, and B. L. Larson. 1979. Endogenous production of immunoglobulin lgG1 in newborn calves. J. Dairy Sci. 62:1814-1818.

Foley, J. A., and D. E. Otterby. 1978. Availability, storage, treatment, composition, and feeding value of surplus colostrum: A review. J. Dairy Sci. 61:1033-1060.

Furman-Fratczak, K., A. Rzasa, and T. Stefaniak. 2011. The influence of colostral immunoglobulin concentration in heifer calves' serum on their health and growth. J. Dairy Sci. 94:5536-5543.

Godden, S. 2008. Colostrum management for dairy calves. Vet. Clin. North Am. Food Anim. Pract. 24:19-39.

Godden, S. M., D. M. Haines, K. Konkol, and J. Peterson. 2009. Improving passive transfer of immunoglobulins in calves. II: Interaction between feeding method and volume of colostrum fed. J. Dairy Sci. 92:1758-1764.

Husband, A. J., M. R. Brandon, and A. K. Lascelles. 1972. Absorption and endogenous production of immunoglobulins in calves. Aust. J. Exp. Biol. Med. Sci. 50:491-498.

Jaster, E. H. 2005. Evaluation of quality, quantity, and timing of colostrum feeding on immunoglobulin $\mathrm{G}_{1}$ absorption in jersey calves. J. Dairy Sci. 88:296-302.
Kehoe, S. I., B. M. Jayarao, and A. J. Heinrichs. 2007. A survey of bovine colostrum composition and colostrum management practices on Pennsylvania dairy farms. J. Dairy Sci. 90:4108-4116.

McGuirk, S. M., and M. Collins. 2004. Managing the production, storage, and delivery of colostrum. Vet. Clin. North Am. Food Anim. Pract. 20:593-603.

Mokhber-Dezfooli, M. R., M. Nouri, M. Rasekh, and P. D. Constable. 2012. Effect of abomasal emptying rate on the apparent efficiency of colostral immunoglobulin G absorption in neonatal HolsteinFriesian calves. J. Dairy Sci. 95:6740-6749.

Morin, D. E., G. C. McCoy, and W. L. Hurley. 1997. Effects of quality, quantity, and timing of colostrum feeding and addition of a dried colostrum supplement on immunoglobulin $\mathrm{G}_{1}$ absorption in Holstein bull calves. J. Dairy Sci. 80:747-753.

Nocek, J. E., D. G. Braund, and R. G. Warner. 1984. Influence of neonatal colostrum administration, immunoglobulin, and continued feeding of colostrum on calf gain, health, and serum protein. J. Dairy Sci. 67:319-333.

Pritchett, L. C., C. C. Gay, T. E. Besser, and D. D. Hancock. 1991 Management and production factors influencing immunoglobulin $\mathrm{G}_{1}$ concentration in colostrum from Holstein cows. J. Dairy Sci. 74:2336-2341.

Quigley, J. D., III, J. J. Drewry, and K. R. Martin. 1998. Estimation of plasma volume in Holstein and Jersey calves. J. Dairy Sci. $81: 1308-1312$.

Quigley, J. D., III, C. J. Kost, and T. M. Wolfe. 2002. Absorption of protein and IgG in calves fed a colostrum supplement or replacer. J. Dairy Sci. 85:1243-1248.

Robison, J. D., G. H. Stott, and S. K. DeNise. 1988. Effects of passive immunity on growth and survival in the dairy heifer. J. Dairy Sci 71:1283-1287.

Roy, J. H. B. 1980. Factors affecting susceptibility of calves to disease. J. Dairy Sci. 63:650-664.

Sakai, R. R., D. M. Coons, and M. Chigerwe. 2012. Effect of single oroesophageal feeding of $3 \mathrm{~L}$ versus $4 \mathrm{~L}$ of colostrum on absorption of colostral IgG in Holstein bull calves. Livest. Sci. 148:296-299.

Stott, G. H., and A. Fellah. 1983. Colostral immunoglobulin absorption linearly related to concentration for calves. J. Dairy Sci 66:1319-1328

Stott, G. H., D. B. Marx, B. E. Menefee, and G. T. Nightengale 1979a. Colostral immunoglobulin transfer in calves I. Period of absorption. J. Dairy Sci. 62:1632-1638.

Stott, G. H., D. B. Marx, B. E. Menefee, and G. T. Nightengale. 1979b. Colostral immunoglobulin transfer in calves II. The rate of absorption. J. Dairy Sci. 62:1766-1773.

Stott, G. H., D. B. Marx, B. E. Menefee, and G. T. Nightengale. 1979c. Colostral immunoglobulin transfer in calves. III. Amount of absorption. J. Dairy Sci. 62:1902-1907.

Weaver, D. M., J. W. Tyler, D. C. VanMetre, D. E. Hostetler, and G. M. Barrington. 2000. Passive transfer of colostral immunoglobulins in calves. J. Vet. Intern. Med. 14:569-577.

Wells, S. J., D. A. Dargatz, and S. L. Ott. 1996. Factors associated with mortality to 21 days of life in dairy heifers in the United States. Prev. Vet. Med. 29:9-19. 